\title{
YOU ARE WHAT YOU EAT: SOME THOUGHTS ON CONSUMPTION AND MARXIST CLASS THEORY
}

\author{
Scott G. McNall \\ University of Toledo
}

Mid-American Review of Sociology, 1990, Vol. XIV, No. 1-2:45-52.

If you are on the left, and especially if you are a Marxist, you are not supposed to be desirous--of sex, cars, or Cuisinarts. An austere life is recommended for the revolutionary, who is to be both lean and mean--sort of an ascetic Rambo. Those who accumulate goods beyond their basic needs are regarded with suspicion and often loathing. But what are basic needs? Remember that Marx, himself, said that human needs are infinitely expandable (Marx 1973/1844). And remember, too, that one central goal of Marx's revolution was to enable the proletariat to live like the bourgeoisie. Even so, consumption is still in bad odor on the left.

Who in their right minds are not distressed by the fact that the publisher/financier Malcolm Forbes spent between \$2-3 million for his Moroccan birthday party in 1989? The excesses of Donald Trump are legend, but he has his counterparts in Japan, England, West Germany, and Switzerland. There are greedy people all over the globe; it takes no effort to find them. It is easy to condemn consumption, not just because of what people do now, but because of its history. In the popular mind, Rome fell because a ruling class was more concerned with circuses than production. In the court cultures of early modern Europe, aristocratic men and women were encouraged to consume with style and grace. When consumption became excessive, it was linked to moral excess, causing the (often Puritanical) lower orders to look upon the unfolding spectacle of consumption with disgust. And, finally, consumption is seen as a feminine activity, and therefore one to be treated as frivolous and meaningless (Mukerji 1989, p. 1462).

Marx viewed consumption negatively because it led to alienation among people. The more you consume, the less human you are. In a nicely paradoxical relationship, each act of consumption eats away at the soul. How? Marx explains, in his well-known discussion of commodity fetishism (Marx 1977/1896). In capitalist societies, workers sell their labor power, and produce commodities, over which they have no control, for exchange. Commodities, be they cars or refrigerators, appear to have intrinsic characteristics, such as weight, color, and size, and they also have a price. Prices are determined by market forces (supply and demand, the cost of labor and materials). Price determines what gets produced as well as how goods are distributed. Goods which bring a high price/profit will be produced, as opposed to those which might meet a greater social need. Prices determine who gets what. The wages paid to the men or women who sell their labor power, determine how much power people have, how much they can buy of the very goods they have produced. Thus, relationships between people are determined by the prices of commodities. Relationships between people--the flesh and blood that 
created the commodities--are presented as relationships between things. As people enter the marketplace, they confront their own alienated labor in the form of the commodity. The commodity, its price, and market relationships all appear as "normal," independent of human activity. Hidden behind the commodity form, however, are the historical struggle of the bourgeoisie and proletariat, the surplus value that has been expropriated, and the relationship of exploitation and domination that characterizes capitalism. It is only by understanding all this, says Marx, that people can understand that their economic order is not inevitable, that it was produced by real people, who can create new orders. That, of course, was why he began Volume I of Capital with a discussion of commodities.

These insights have effected the definitions of class that flow from Marx (see, for instance, the work of Wright 1978, 1985). Exploitation is characteristic of capitalism and occurs, first, at the point of production. One's relationship to the means of production is the primary determinant of political and economic power, and by extension, one's self. Marx, drawing on Hegel, argues that people realize themselves as human beings through transformations of the material world, though laboring. Thus, most Marxist and neo-Marxist class theorists, who are bent on mapping the contemporary class structure of American society, set out to define people's class position by privileging production, by looking at whether or not people control others, or are controlled by them (Abercrombie and Urry 1983; Burawoy 1979; Carchedi 1977; Wright 1978, 1985). The job people have, or do not have, becomes the determining variable for categorizing them and others like them. Gone from the picture are such Weberian concerns as status and style of life.

It is my contention that the failure of a Marxist framework to deal seriously with the issue of consumption is a major problem, and limits our ability to understand the class structure of contemporary societies. Maybe production is no longer central to people's lives and the development of social relations. Maybe Marx needs to be updated. Now, and I think this needs to be made clear, I am not arguing that we do not live in a class society, or that all that distinguishes one person from another is whether they drive a Chevrolet or a Porsche, drink Bud or Perrier. Exploitation is still a key element of modern society; there are still class struggles. But the struggle is over consumption. The struggle is over money, the power to consume, and not whether a person does or does not own the means of production, a concept of increasingly dubious value.

Let us think for a moment about contemporary America without a priori theories. What do we make of the fact that in some neighborhoods, women have organized coupon clubs for the purpose of alerting one another to bargains at local stores, and trading coupons? Who hasn't been told, "I could have gotten it for you wholesale," or at least, "I know somebody who could have gotten a deal on it for you." Yuppies, the old rich, garage mechanics and housewives are all looking for a good deal. And why not? Shopping smart is not necessarily a sign that one has bought into consumer culture--after all, we do have to eat and provide ourselves with shelter. But people derive real gratification and even a sense of self worth, even if those on the left don't think they should, from being intelligent consumers. Isn't Consumer Reports produced for the sole purpose of making it possible to buy the right stereo, bike, back packing equipment, blender, and toaster, and getting the right price? It seems to me that what the left often worries about, but doesn't say, is that people don't consume the right things. The idea that the working class mind is numbed to the possibilities of revolution by beer and chips is not entirely plausible. Is the desire of a working-class family to own a washer, dryer, refrigerator, television set, and car really a sign that they are engaged in some form of mindless hedonism?

Madonna sings, "I'm just a material girl." Bumper stickers proclaim: "When the tough gets going, the tough go shopping." "Born to shop." "I brake for garage sales." "Who ever has the most toys when he dies, wins." "Spending our children's inheritance," which usually appears on Winnebagoes or their clones. "Shop 'til you drop." Come on, America, consumption is fun. It is the reason why people work. Should people, who are weary from dull jobs, be denied the pleasure which is to be found in consumption? Might consumption even, dare we say this word, be meaningful?

It is time again for theory. Remember that Marx borrowed his concept of the laboring human being, realizing her or himself through work and transformation of the material world, from Hegel. Marx believed that people overcame alienation through work that allowed them to realize their full human potential. (He did not mean factory labor [Marx 1973/1844].) If we stick to the original insight, borrowed from Hegel, we can hold fast to the idea that people realize their unique natures, become part of larger communities, overcome their alienation, materially. The subject and object are, as dialectics tells us, wedded, not two separate phenomenon. People are social animals; that is what it means to be human in both a Hegelian and Marxian sense--to realize one's fullness, and to achieve full ego development, through membership in and identification with a larger human community. How, in fact, do people do this? Through, I am arguing, the use and manipulation of artifacts (material objects) that have social meaning or have social meanings imparted to them (cf., Miller 1987, pp. 3-17; 178-217). Thus, objects produced in one setting (which may or may not represent alienated labor) can be appropriated and used in another setting to realize oneself, to identify with a larger community, to overcome alienation. In short, people and cultures learn about who they are through the objects they produce and consume.

The clearest memories I have of my father during the time I was growing up are, I think, an illustration of my point. Over the course of his life he had a variety of different jobs, most of them, by his own testimony, not very interesting. He worked hard and spent his leisure time, such as it was, "fixingup" the house. In fact, "fixing-up" the houses we lived in was his consuming activity and passion. He laid patios and sidewalks, put in new bathrooms, made an attic over into a master bedroom (though there was no such term then), rebuilt a garage to make a study for me, planted shrubs, painted, moved doorways, enclosed porches, made ponds and grottoes and other things I have 
long forgotten. His sense of self, though you will have to take my word for this, was defined not by the jobs he had--he was, at different times, a farmer, small-businessman, manager, and blue-collar worker--but by his work around the house. My mother, who was a special-education teacher, complained about her work and made it clear, like my father, that the reason they worked was to have a nice home, and to be able to fill it up with things that symbolized to themselves, their relatives, and the neighbors that they were respectable, middle-class people.

While my father was puttering around the house, and my mother was canning, washing clothes, or working in the garden, I usually played. But as I approached my sixteenth birthday all of my interests and energies were focused around one, all-consuming goal: owning that symbol of alienated labor, an automobile. I had already worked two summers picking berries and in a greenhouse, to get enough money to buy a car. I pestered my father continually until he agreed that I could get one a full three months before I turned sixteen. I backed it in and out of the driveway, washed and polished it, had new naugahyde seatcovers installed, replaced the old hubcaps with full moons, bullnosed the front end (which means, to the uninitiated, that I took off the hood ornament and put on a rounded piece of chrome), leaded the trunk lid, and had the car repainted. In short, I made the car mine. Why did I spend all that time on the car, why did I covet it so? Because a car, an object, meant that I could date without having to tag along with somebody older; it meant that I no longer had to ride the school bus; it meant that I could visit my friends who lived some distance away (I went to a rural consolidated high school); it meant, above all, that I was no longer a kid. My parents, of course, had different ideas, but that is beside the point. My self was created through the use of material objects that had a distinct cultural meaning. By owning a car, I became a member of a larger community--albeit of high school teenagers. There can, then, be a positive relationship between people and things.

There are two points to make about this observation. The first involves a basic sociological insight: our selves are not given; they are socially constructed and objects play a part in that construction. The second point is that we do not always use objects in the construction of the self in the way in which they were originally intended. The meaning of the first point can be clarified by a cross-cultural example. Strathern (1979) has discussed the meaning of face painting among the New Guinea highlanders. For the New Guinea highlander the face that one is born with is an arbitrary matter. Whether or not it is handsome by our standards is beside the point. The face is not a representation of the real self. The real self is revealed only after the face has been worked upon, through the elaborate use of cosmetics and line drawings. From our perspective, the highlander is "made up." From the highlander's perspective, he or she is laying bare his or her soul before the world, once the make-up is applied. Furthermore, and this is partial support for our second point, the objects used to decorate the body and reveal the self may be feathers or shells, they may be purchased with cash or the traditional salt, feathers may be obtained with the use of bow and arrow, or birds brought down with guns. The meaning of the object is determined by its use and social context; it is not predetermined.

More on the second point, because it deserves elaboration. From a Marxian perspective, consumption is seen as a passive act. If agency is involved at all, it is because people are seen as dupes wandering dazedly and forlornly up and down the isles of K-Mart and Wal-Mart, ever searching for and never finding their communal selves. But that is not how most people consume. Take the example of teenagers buying records and tapes, a multibillion dollar a year business. Youth use the music they buy in many ways: to listen to in solitude, to drown out their parents, to organize parties around, and in order to be able to talk to one another about the music and the individuals and groups who create and perform it. As Grossberg (1988, p. 140) tells us, they seldom use it in any straightforward manner. "[T]heir power lies in their ability to appropriate any text, to undermine the distinction between production and consumption and, in this way, to deny the power of ideology and of the commodity itself."

A gift is an object, which in one context may represent pure alienated labor, as would be the flowers sent to the United States from Columbia, where they are grown and picked by underpaid laborers. Maybe we are reminded by an advertisement to purchase flowers for our mother, father, or sweetheart, but once we do so, and once we give them away, the flowers take on a new, social meaning. We have used the purchase of a commodity to forge a social bond. Cynical as some may be about birthdays, Christmas, Hanukkah, or anniversaries, the fact remains that the gifts that are given and received have a meaning that transcends the object. "It's the thought that counts." The meaning of objects is determined by a social and cultural context. We appropriate objects and recontextualize them. My first car, a 1948 Plymouth, was designed as an efficient means of family transportation. It had a different meaning for me, just as today's low-riders or the custom cars of the 1960 s, had a different meaning for their owners than the one originally intended.

Let us return to the isles of Wal-Mart. Granted that some people may fill up their carts up with things they could do without; many people shop at Wal-Mart, and not its upscale equivalent, because that is where they can afford to shop. And, a lot of what people have in their carts are socks, shirts, and kitchenware, which I doubt even Marx would deny them. But people who buy goods are not just meeting a basic need for food, shelter, or warmth. They are also signaling to others such important things as whether or not they are good housewives, or whether or not they are good providers. We actively purchase and consume, engage in display of our goods, as a way of "telling" people who we are, or who we wish to become. I know my parents and others of their generation are not the only people who have sent snapshots of their new breakfast buffet or refrigerator to their distant children, because my younger friends have suffered through the same experience. A trip home is a visit to new goods or projects and a dutiful tour around the house and yard. 
It still drives me crazy, but the reason for the display is pretty clear: the use of and manipulation of goods, often in ways probably not intended by the manufacturers, signals success in a desirable social role. A new freezer or refrigerator means meals and cookies can be made and stored for the return of children and grandchildren, because that is what grandmothers do. The object helps the individual to realize and fulfill an important idea of self.

Consumption aids in the construction of community, whether we are talking about consumer durables or ideology, which comes to us in the form of radio, television and the movies. In spite of tomes written to the contrary, watching television is not just a passive act. People appropriate the scripts, criticize them, and chew them over with co-workers and family members. Except for those with severe mental handicaps, people don't take television seriously. That is, they understand it is not real, though they do use it to construct the social, and to define cohorts, including generational cohorts. Factory and office workers may discuss in great detail a televised baseball or football game, the plot of a favorite soap opera, or what happened on "Dallas" or "Dynasty." Retirees may talk about golf, and teenagers may discuss MTV. All are likely to discuss the news. The fact that theorists might not like mass culture is neither here nor there. Watching TV is not qualitatively different from elite intellectual activity, if we are thinking about the construction of everyday reality. The first academic department of which I was a member had a morning ritual that involved talking about the New York Times. One prodded colleagues to see if they had read the same story as you, what they had made of it, and so forth. If you had not read the paper, you either had to fake it, or avoid your colleagues. Those who did not participate in the morning ritual were not part of the "group."

Perhaps I can sum up. When Marx wrote, production was central to people's lives. Now, I am suggesting, our selves are not formed at the point of production but at the point of consumption. Today's struggles are not over who shall control the means of production, they are over whether or not people will have the money to live a decent life. This is, of course, a strong argument. Halle (1984) has argued that there are three sites in which people's identify is formed: at work in the community, and in the home. I do not wish to deny the importance of the job, but from my perspective we would do well to consider how much people get paid, rather than dwell on whether or not they control other workers, or whether they work with their heads or their hands. Neighborhoods in America are stratified less by race than by income. Whether or not one maintains an upper-, middle-, or lower-class life style depends on income, not just the kind of job one has (Ehrenrich 1989). Furthermore, it is not at the point of production that class and inequality reproduce themselves: it is in the educational system, and educational opportunities are, overwhelmingly, determined by financial status. There is a widening gap in American society; a gap between those who can live well, and those who cannot. We need no elaborate measures to gauge people's relative positions. We can rely on the those two shop-worn variables of 1950 s and 1960s stratification researchers: education and income.
Again, this is not to reduce struggle and exploitation to a matter of styleof-life. It is to see consumption as a relevant and meaning activity; to understand that today's class battles and power struggles are over consumption. Seldom is political and class conflict directed against the capitalist class or employers; usually, it is aimed at a political regime (Miller 1989). Americans have politicized consumption and believe it is the government's responsibility to make things better. It is helpful to remember that the 1989 student pro-democracy movement in China revolved around three basic issues: the corruption of government officials, the failure of the government to curb inflation, and the failure of the government to provide good jobs for university graduates (Calhoun 1989). All of these issues relate, or can be related, to consumption. (Democracy in China did not mean, to movement participants, that they wanted to vote in multi-party elections.) Modern governments determine, through fiscal and monetary policies, whether the economy grows or declines, whether women will be able to enter the labor force or not, whether education will be available to all, or rigidly stratified. Americans are class-conscious, all right, but the dividing line is not the traditional one between a class-consciousness proletariat, the middle classes, and the bosses (cf. Vanneman and Cannon 1987). It is between the "haves" and the "have nots." As Ernest Hemingway once explained to F. Scott Fitzgerald's plaintive question about the rich: "The difference is that they have money!"

\section{REFERENCES}

Abercrombie, Nicholas, and John Urry. 1983. Capital Labor and the Middle Classes. London: Allen and Unwin.

Burawoy, Michael. 1979. Manufacturing Consent. Chicago: University of Chicago.

Calhoun, Craig. 1989. "Protest in Beijing: The Conditions and Importance of the Chinese Student Movement of 1989." Partisan Review, forthcoming, fall.

Carchedi, Guglielmo. 1977. On the Economic Identification of Social Classes. London: Routledge and Kegan Paul.

Ehrenreich, Barbara. 1989. Fear of Falling: The Inner Life of the Middle Class. New York: Pantheon.

Grossberg Lawrence. 1988. 'Rockin' With Reagan, or the Mainstreaming of Postmodernity." Cultural Critique 10:123-149.

Halle, David. 1984. America's Working Man. Chicago: University of Chicago Press.

Marx, Karl. 1973/1844. The Economic and Philosophic Manuscripts of 1844 Dirk J. Struik, ed., New York: International Publishers. 1977/1896. Capital. Vol. I. New York: Vintage Books.

Miller, Daniel. 1987. Material Culture and Mass Consumption. Oxford: Basil Blackwell. 
Mid-American Review of Sociology

Miller, S.M. 1989. "Rethinking Stratification: Class Analysis for the American '90s." Paper presented at the conference, "Bringing Class Back In." Lawrence, Kansas.

Mukerji, C. 1989. "Review of Material Culture and Mass Consumption." American Joumal of Sociology 94:1462.

Strathern, M. 1979. "The Self in Self Decoration." Oceania 44:241-257.

Vanneman, Reeve, and Lynn Weber Cannon. 1987. The American Perception of Class. Philadelphia: Temple University Press.

Wright, Erik O. 1978. Class, Crisis and the State. London: New Left Books. . 1985. Classes. London: Verso Books.

\section{A FORMULATION OF PROFIT SEEKING ORGANIZATIONS: CAPITAL ACCUMULATION, IRRATIONALITY, AND POLITICS}

Harland Prechel

University of Maryland Baltimore County

Mid-American Review of Sociology, 1990, Vol. XIV, No. 1-2:53-65.

This essay is critical of traditional conceptions of organizations, which attempt to develop models and propositions that apply to all kinds of organizations, employ nomothetic ahistorical methods, or assume that organizational change is an outcome of rational managerial decisions. In contrast to these mainstream perspectives, the theoretical framework herein is anchored in the Marxian and radical Weberian traditions in organization theory. This essay suggests that the need to accumulate capital and the emphasis on cost accounting principles, to determine its income yielding power, distinguishes profit seeking organizations from other kinds of organizations. Moreover, the tendency of mainstream organizational theory to assimilate Weber's distinction between substantive rationality and formal rationality conceals the profoundly political nature of strategic decisions, and the effects of irrationalities on organizational change.

The study of complex organizations has been guided by rational theories and methodologies that attempt to establish models and propositions that apply to all organizations over an indefinite time span. In contrast, this essay: (1) advances a conception of profit seeking organizations that articulates how extra-organizational processes and internal irrationalities effect organizational change, and (2) asserts that a conceptual framework that grasps the unique characteristics of profit seeking organizations is necessary to advance our understanding of these kinds of organization.

The theoretical framework is anchored within the Marxian and radical Weberian traditions in organizational theory. The analysis herein is Marxian to the extent that it emphasizes internal organizational crises (e.g., Benson 1977a, 1977b; Heydebrand 1977, 1985; Zeitz 1980), and the effect of capital accumulation opportunities and constraints in the organization's economic environment (Clegg 1981; Prechel 1987). This conception of profit seeking organizations also stresses the Weberian emphasis on economic considerations in the rationalization process, and the political dimension of managerial decision making as matters of choice rather than inevitable outcomes of historical process (e.g., Clegg 1981; Clegg, Boerham, and Dow 1986; Clegg and Dunkerley 1980; McNeil 1978). In addition, this essay identifies how Weberian theory is useful to identify organizational irrationalities. 